
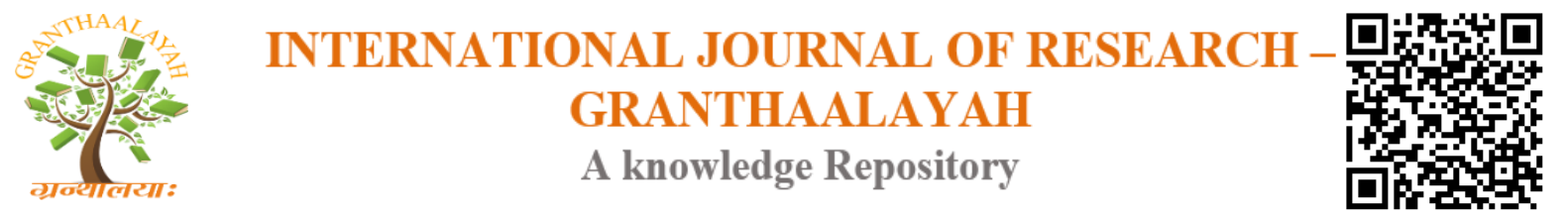

Science

\title{
HOMOGENEOUS VINYLATION OF 2-HYDROXY-2 PHENYLETHANICAL ACID
}

\author{
Parmanov A.B. " ${ }^{\text {, }}$ Nurmanov S.E. 1, Tomash Maniecki ${ }^{2}$, Ziyadullayev O.E. ${ }^{\text {, }}$ \\ Abdullayev J.U. 1 \\ ${ }^{*} \mathrm{PhD}$ student, National university of Uzbekistan, Tashkent, Uzbekistan \\ ${ }^{2}$ Professor, Lodz University of Technology, Lodz, Poland
}

\begin{abstract}
Homogeneous-catalytical vinylation of 2-hydroxy-2-phenylethanical acid was carried out. Influence of catalylists nature, temperature and duration reaction on yield of synthesized vinyl ester has been investigated.

basis of natural raw materials. Based on vinyl esters of carboxylic acids, their polymers and copolymers with unsaturated compounds of the ethylene series, emulsifiers for emulsion paints have been obtained; compounds that improve the viscosity of lubricating oils and are used as crosslinking agents in the rubber industry. Synthesis of vinyl esters based on monobasic aliphatic acids has been studied by the example of acetic acid by many researchers. In this respect, the aromatic carboxylic acids remain unexplored.

Goal: Synthesis of vinyl ester of mandelic acid by it's reaction with acetylene in the presence of heterogeneous catalysts, investigation of the influence of the nature of catalysts and the reaction temperature on the yield of obtained product.

Methodology: Catalytic systems based on $\mathrm{AlCl}_{3} \cdot 6 \mathrm{H}_{2} \mathrm{O}$ or zinc salt of mandelic acid with dimethylsulfoxide were prepared and heterogeneous catalytic vinylation of mandelic acid with acetylene was carried out and it's vinyl ether was obtained.

Scientific Novelty. The synthesis of vinyl ester of mandelic acid with it's reactions with acetylene using the catalytic systems $\mathrm{AlCl}_{3} \cdot 6 \mathrm{H}_{2} \mathrm{O}-\mathrm{DMSO}$ and $\left(\mathrm{C}_{6} \mathrm{H}_{5} \mathrm{CH}(\mathrm{OH}) \mathrm{COO}\right)_{2} \mathrm{Zn}-\mathrm{DMSO}$ was carried out.

Obtained Data: The vinyl ester of mandelic acid was synthesized by it's vinylation in stationary heterogeneous conditions. The influence of the nature of the catalyst $\left(\mathrm{AlCl}_{3} \cdot 6 \mathrm{H}_{2} \mathrm{O}\right.$, $\left.\left(\mathrm{C}_{6} \mathrm{H}_{5} \mathrm{CH}(\mathrm{OH}) \mathrm{COO}\right)_{2} \mathrm{Zn}\right)$, temperature and duration of the reaction on the yield of the product was investigated.

Features:

- vinylation of hydroxy carboxylic acid was investigated;

- the catalytic systems $\mathrm{AlCl}_{3} \cdot 6 \mathrm{H}_{2} \mathrm{O}-\mathrm{DMSO}$ and $\left(\mathrm{C}_{6} \mathrm{H}_{5} \mathrm{CH}(\mathrm{OH}) \mathrm{COO}\right)_{2} \mathrm{Zn}$-DMSO are used;

- factors influencing the yield of vinyl ester of mindalic acid and optimal conditions of it's synthesis were found.
\end{abstract}

Keywords: Mindalic Acid; Acetylene; Heterogeneous Catalysis; Influencing Factors on Product Yield; Catalysts: $\mathrm{AlCl}_{3} \cdot 6 \mathrm{H}_{2} \mathrm{O}$ and $\left.\left(\mathrm{C}_{6} \mathrm{H}_{5} \mathrm{CH}(\mathrm{OH}) \mathrm{COO}\right)_{2} \mathrm{Zn}\right)$. 
Cite This Article: Parmanov A.B., Nurmanov S.E., Tomash Maniecki, Ziyadullayev O.E., and Abdullayev J.U.. (2018). "HOMOGENEOUS VINYLATION OF 2-HYDROXY-2 PHENYLETHANICAL ACID." International Journal of Research - Granthaalayah, 6(11), 350-354. https://doi.org/10.29121/granthaalayah.v6.i11.2018.1138.

\section{Introduction}

Vinyl esters are important compounds because owing to presence in their molecules of double bond and ether group on their base different chemical transformations can be carried out. Such compounds are wide used at obtain dyes, at production of monomer for obtain different polymers. On the base of vinyl esters of carbonic acids, their polymers and copolymers were obtained also compounds, on their base containing double bond were used for obtain which were used at obtain of different emulgators and dyes; compounds improving viscosity of lubricates and cross-linking agents for rubler-technical industry also have been obtained. At present time the high demands to polymerical materials is caused by concuration what has carried out to increasing of quality of products and their cost. Also using of natural compounds in this range also is very important $[1,2]$. 2-Hydroxy-2-phenylethanical acid (mandelic acid) is an natural compound wich is entered in composition of mendale. On it's base antiseptics using in medicine as initial compounds for obtain antibiotics were obtained. It's ammonium and calcium salts are used as urinegonic substances in urology. Also it is used as analytical reagent for determination of ions of $\mathrm{Ti}, \mathrm{Fe}, \mathrm{Al}, \mathrm{Cr}, \mathrm{V}$ and for devision of $\mathrm{Zn}$ from Mo [3-5]. Acid properties of investigated acid are hier in comparision with acetic acid what is influced on it's biological activity and limited spheres of it's using. By this reason decreasing of it's acid properties has allowed to increase biological activity of mandelic acid. According to above mentioned in this work gomogeneous-catalytical vinylation of mandelic acid was carried out in solution of dimethylsulfoxide (DMSO) in the presence of catalysts-zink salt of mandelic acid and it's composition with $\mathrm{AlCl}_{3} \cdot 6 \mathrm{H}_{2} \mathrm{O}$ at temperature $80-140{ }^{0} \mathrm{C}$. Acetylen has been past through mixture mandelic acid-DMSO-catalyst with rate $0,1 \mathrm{~mole} / \mathrm{h}$. At this vinyl ester of mandelic acid was formed as main product according to following scheme:<smiles>C=COC(=O)C(O)c1ccc(C(C)C(C)C(=O)OC(C)C)cc1</smiles>

Obtained ester is a new organical compound unknown in literature and it's some physico-chemical properties are presented in table 1 .

Table 1: Some physico-chemical properties of vinyl ester mandelic acid

\begin{tabular}{|l|l|l|l|l|l|}
\hline Structural formule & $\begin{array}{c}\text { Yield, } \\
\%\end{array}$ & \multicolumn{2}{|c|}{ Data of IR-spectrometry } & \multicolumn{2}{|c|}{$\begin{array}{c}\text { Data of PMR- } \\
\text { spectrometry }\end{array}$} \\
\hline \multirow{2}{*}{84,4} & $\begin{array}{l}\text { characteristical } \\
\text { groups }\end{array}$ & $\begin{array}{l}\text { value of, } \\
s m^{-1}\end{array}$ & $\begin{array}{l}\text { characteristical } \\
\text { groups }\end{array}$ & $\begin{array}{l}\text { value } \\
\text { of, } \text { m.d. }\end{array}$ \\
\cline { 3 - 6 } & & 3430,28 & $\mathrm{OH}$ & 2,0 \\
\cline { 3 - 6 } & $\mathrm{OH}$ & 2917,35 & & \\
\cline { 3 - 6 } & $\mathrm{CH}-(\mathrm{OH})$ & 1712,09 & $=\mathrm{CH}_{2}$ & $\begin{array}{l}4,85- \\
4,55\end{array}$ \\
\cline { 3 - 6 } & $\mathrm{C}=\mathrm{O}$ & & &
\end{tabular}




\begin{tabular}{|c|c|c|c|c|}
\hline \multirow{3}{*}{ 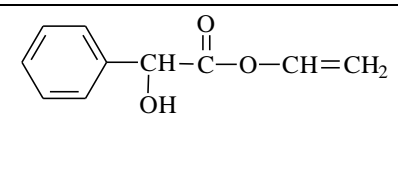 } & $\mathrm{CH}=\mathrm{CH}_{2}$ & 1663,14 & $=\mathrm{CH}$ & 7,25 \\
\hline & $(\mathrm{Ar})=\mathrm{CH}$ & 3003,11 & $-\mathrm{CH}$ & 5,34 \\
\hline & $\begin{array}{l}\text { C-О-С } \\
\text { (симм. валент) }\end{array}$ & 1025 & $\mathrm{C}_{6} \mathrm{H}_{5}$ & $\begin{array}{l}7,38- \\
7,36\end{array}$ \\
\hline
\end{tabular}

Temperature has influensed in great degree on carring out of investigated catalytical reaction. By this reason the influence of this parameter on the vinylation of mandelic acid by acetylene in the presense of it's Zn salt as catalyst has been investigated and obtained results are presented in table 2.

Table 2: Influence of temperature on vinylation of mandelic acid in the presence of it's zink salt $(10 \%)$ as catalyst and rate of acetylene past through $0,1 \mathrm{~mole} / \mathrm{h}$

\begin{tabular}{|l|l|l|}
\hline № & Temperature of reaction, ${ }^{\mathbf{0}} \mathbf{C}$ & Yield of vinyl ester, $\%$ \\
\hline 1 & 80 & 45,8 \\
\hline 2 & 90 & 49,4 \\
\hline 3 & 100 & 56,6 \\
\hline 4 & 110 & 63,2 \\
\hline 5 & 120 & 65,9 \\
\hline 6 & 130 & 61,5 \\
\hline 7 & 140 & 53,4 \\
\hline
\end{tabular}

As shown from obtained results the great influence on vinylation of mandelic acid by acetylene the temperature has rendered. In investigated range of temperature $80-140{ }^{\circ} \mathrm{C}$ it's vinyl ester was formed yield of wich has changed with temperature: increasing of temperature from 80 to $120{ }^{\circ} \mathrm{C}$ caused to increasing of product yield from 45,8 to $65,9 \%$ and following increasing of temperature befor $130{ }^{\circ} \mathrm{C}$ has caused it's decreasing and at this also decomposition of DMSO with formation of sulfer-containing compounds with following formation cross-linking oligomeric products was observed. For vinylation of mandelic acid by acetylene the optimal temperature was $120^{\circ} \mathrm{C}$ and at this yield of forming vinyl ester was equaled $65,9 \%$ and correspondenly following investigations were carried out namely at this temperature. In table 3 results by influence of temperature on vinylation of mandelic acid in the presence of it's zink salt treatment by $\mathrm{AlCl}_{3} \cdot 6 \mathrm{H}_{2} \mathrm{O}(10 \%)$ as catalyst are presented.

Table 3: Influence of temperature on vinylation of mandelic acid in the presence of abovementioned catalyst (time- $2 \mathrm{~h}$; rate of acetylene past through $0,1 \mathrm{~mole} / \mathrm{h}$ )

\begin{tabular}{|l|l|l|}
\hline № & Temperature of reaction, ${ }^{\mathbf{} C}$ & Yield of synthesised vinyl ester, $\%$ \\
\hline 1 & 80 & 65,3 \\
\hline 2 & 90 & 68,7 \\
\hline 3 & 100 & 69,6 \\
\hline 4 & 110 & 73,9 \\
\hline 5 & 120 & 79,8 \\
\hline 6 & 130 & 67,5 \\
\hline 7 & 140 & 63,4 \\
\hline
\end{tabular}


From obtained results it is shown that in presence of elaborated catalyst in temperature range 80$120{ }^{0} \mathrm{C}$ yield of forming vinyl ester of mandelic acid has increased from 65,3 to 79,8 and at this introduct ion of $\mathrm{AlCl}_{3} \cdot 6 \mathrm{H}_{2} \mathrm{O}$ in composition of catalyst has increased it's catalytical activity.

It is known that in stationary state on the rate of chemical reaction and yield of product the duration of reaction (time) has a very important role. By this reason the influence of this factor on the formation of the base product-vinyl ester of mandelic acid was investigated and obtained results are presented in table 4.

Table 4: Influence of process duration on vinylation of mandelic acid in the presence of it's zink salt as catalyst, rate of feeding of acetylene $0,1 \mathrm{~mole} / \mathrm{h}$, temperature $120{ }^{\circ} \mathrm{C}$

\begin{tabular}{|l|l|}
\hline Duration of reaction, $\mathbf{h}$ & Yield of vinyl ester of mandelic acid, \% \\
\hline 1 & 48,7 \\
\hline 2 & 65,9 \\
\hline 3 & 69,7 \\
\hline 4 & 71,1 \\
\hline 5 & 69,8 \\
\hline 6 & 67,2 \\
\hline
\end{tabular}

It is shown that yield of obtained vinyl ester was increaser from 48,7 to $71,1 \%$ correspondenly at increasing time of reaction from 1,0 to $4,0 \mathrm{~h}$, but at following increasing of duration of reaction yield of product has decreased on 1,3-2,6\% that is optimal duration of carring out of investigated reaction was equaled $4 \mathrm{~h}$.

According to data of chromatographical analysis at time of reaction $3 \mathrm{~h}$ beside of base product also mandelic acid didn't entered in reaction was observed; at time of reaction more then $4 \mathrm{~h}$ also formation of rubber-similar compounds owing to oligomerisation and polymerization of obtained vinyl ester and it's cross-linking by $\mathrm{H}_{2} \mathrm{~S}$ forming owing decomposition of solvent DMSO was observed.

At investigation of vinylation of mandelic acid in the presence of it's salt $+\mathrm{AlCl}_{3} \cdot 6 \mathrm{H}_{2} \mathrm{O}(10 \%)$ as catalyst have been obtained results, precented in table 5 .

Table 5: Influence of duration of vinylation mandelic acid in the presence of above mentioned mixing catalyst at temperature $120^{\circ} \mathrm{C}$ and rate feeding of acetylene $0,1 \mathrm{~mole} / \mathrm{h}$

\begin{tabular}{|l|l|}
\hline Duration of reaction, $\mathbf{h}$ & Yield of vinyl ester of mandelic acid, \% \\
\hline 1 & 56,5 \\
\hline 2 & 79,8 \\
\hline 3 & 83,2 \\
\hline 4 & 84,4 \\
\hline 5 & 82,9 \\
\hline 6 & 81,1 \\
\hline
\end{tabular}

From data of table 5 it is shown that introduction in composition of catalyst ingradient $\mathrm{AlCl}_{3} \cdot 6 \mathrm{H}_{2} \mathrm{O}$ has increased it's activity owing to fact that it implements role of promotor. In the presence of this catalyst yield of vinyl ester during 1-4h was increased from 56,5 to $84,4 \%$. 


\section{Conclusions}

It was shown that at vinylation of mandelic acid by acetylene in the presence of catalyst $\left(\mathrm{C}_{6} \mathrm{H}_{5} \mathrm{CH}(\mathrm{OH}) \mathrm{COO}\right)_{2} \mathrm{Zn}$ the it's vinyl ester has been formed.

It was determined that introduction in composition of catalyst ingradient $\mathrm{AlCl}_{3} \cdot 6 \mathrm{H}_{2} \mathrm{O}(10 \%)$ as promotor has caused increasing of yield of forming vinyl ester.

It was determined that temperature, duration of reaction and nature of used catalyst have great influence degree on the yield of vinyl ester of mandelic acid.

\section{References}

[1] Parmanov A.B., Nurmanov S.E., Phayzullaeva M.Ph., Abdullaev J.U., Soliev M.I. "Synthesis of vinyl esters of some carbonic acids". Austrian journal Technical and Natural Science 2017y №1-2 129-132 p.

[2] Ioan-TeodorTrotus, Tobias Zimmerman, Ferdi Schuth. "Catalytic reactions of acetylene": A Feedstock for the Chemical industry revisited. Chem.Rev. 2014, 114, 1761-1782.

[3] Stanley R., Sandler. Atmospheric vinylation of several haloacetic acids and benzoic acid by acetylene. Journal of chemical engineering data, vol. 18, No. 4, 1973, pp. 445-448.

[4] Ye et al.: "Synthesis and structure of some ruthenium-rhenium heterodinuclear complexes and their catalytic activity in the addition of carboxylic acids to phenylacetylene" Journal of organometallic chemistry, vol. 691, no. 6, 1216-1222, 2006.

[5] Transition-metal-catalyzed addition of Heteroatom-Hydrogen Bonds to alkynes, Alonso et al., Chem. Rev., 2004, 104 (6), 3079-3160

*Corresponding author.

E-mail address: asqar.parmanov@ mail.ru 